\title{
Management outcomes of ectopic pregnancy depending on different treatment modalities: a cohort study
}

\author{
Shawqi H. Alawdi ${ }^{1,2}$, Mayada Roumieh ${ }^{3,4}$, Marwan Alhalabi ${ }^{3,4,5 *}$

\begin{abstract}
${ }^{1}$ Department of Pharmacology, Faculty of Pharmacy, International University for Science and Technology (IUST), Syria ${ }^{2}$ Department of Pharmacology, Faculty of Medicine, Thamar University, Yemen

${ }^{3}$ Department of OBGYN, ${ }^{4}$ Maternity Hospital of OBGYN Faculty of Medicine, Damascus University, Syria

${ }^{5}$ Division of Reproductive Medicine, Embryology and Genetics, Faculty of Medicine, Damascus University, Syria
\end{abstract}

Received: 22 January 2021

Revised: 07 February 2021

Accepted: 08 February 2021

\section{*Correspondence:}

Dr. Marwan Alhalabi,

E-mail: profalhalabi@gmail.com

Copyright: $\odot$ ( the author(s), publisher and licensee Medip Academy. This is an open-access article distributed under the terms of the Creative Commons Attribution Non-Commercial License, which permits unrestricted non-commercial use, distribution, and reproduction in any medium, provided the original work is properly cited.

\section{ABSTRACT}

Background: Ectopic pregnancy is the most common cause of maternal morbidity and mortality during the first trimester of pregnancy. The present study aimed to review and evaluate the management outcomes of ectopic pregnancy in Damascus University Maternity Hospital, Syria.

Methods: A retrospective cohort study was performed on women referring to Damascus University Hospital of Obstetrics and Gynecology (OBGYN) for ectopic pregnancy. Patients were assigned into groups by method of treatment: expectant management (Group 1), single-dose methotrexate regimen (Group 2), two-dose methotrexate regimen (Group 3), and surgical intervention (Group 4). Parameters assessed were risk factors for ectopic pregnancies, transvaginal ultrasonography findings, serum human chorionic gonadotropin (hCG) levels on Days $0,4,7$, and types of surgical intervention in women that underwent any surgical intervention. A treatment modality was considered successful when hCG levels declined to less than $5 \mathrm{mIU} / \mathrm{L}$ without further administration of methotrexate dose or need for surgery.

Results: Seventy-seven women with ectopic pregnancy were admitted to the hospital during the study period. Groups $1,2,3$, and 4 constituted $20.8 \%, 13.0 \%, 6.5 \%$ and $59.7 \%$ of the patients respectively. The most common encountered risk factors for ectopic pregnancy in the patients were history of previous intra-abdominal or pelvic surgery $(57.1 \%)$ and history of miscarriage $(41.6 \%)$. A statistically significant difference in the serum hCG concentrations measured on day 0 , day 4 , and day 7 were observed between the groups.

Conclusions: The success rate in ectopic pregnancy treatment was $56.25 \%$ for the expectant management, $70 \%$ for the single-dose methotrexate regimen, and $40 \%$ for two-dose methotrexate regimen.

Keywords: Tubal pregnancy, Ectopic pregnancy, Methotrexate, hCG

\section{INTRODUCTION}

Ectopic pregnancy is almost the most common cause of maternal morbidity and mortality during the first trimester of pregnancy. ${ }^{1}$ It involves implantation and subsequent development of the embryo at an abnormal site other than the normal site of within the endometrium. ${ }^{2,3}$ The embryo is not able to grow normally when it is implanted in other places than the uterus which is designed to accommodate the embryo and its growth needs. Hence, it will almost results in abortion or rupture. ${ }^{4}$ Treatment of ectopic pregnancy includes three approaches: surgical, medical, and expectant management. Expectant management is an option for hemodynamically stable women with minimal 
symptoms, small ectopic mass, no rupture findings on transvaginal ultrasonography, and compliant with followup at least weekly with serial serum hCG. ${ }^{1,5}$ Medical treatment with methotrexate, a folinic acid antagonist that inhibits nucleic acid synthesis by deactivating dihydrofolate reductase enzyme, is the preferred costeffective choice for women with unruptured ectopic pregnancy. $^{6}$ Surgical intervention is offered for hemodynamically unstable patients or patients with acute abdominal findings of ruptured ectopic pregnancy. ${ }^{7}$

In this present study, we reviewed all ectopic pregnancy cases admitted to Damascus University Hospital of OBGYN, Syria between January 1, 2019 and December 31,2019 . The outcomes of the four treatment modalities of ectopic pregnancy were compared.

\section{METHODS}

\section{Study design and population}

This retrospective cohort study reviewed all diagnosed cases with ectopic pregnancy in Damascus University Maternity Hospital of OBGYN, Syria for the period between January, 2019 and December, 2019. The study was approved by the institutional ethics committee. Data on the ectopic pregnancy treatment were collected from the hospital medical records and patients' files and were analyzed retrospectively. Sociodemographic characteristics included age, smoking, clinical presentation, gestational age, gravidity, parity, history of using contraceptive methods, history of ectopic pregnancy, history of previous pelvic or abdominal surgery, history of infertility treatment, history of miscarriage, transvaginal ultrasonography findings (gestational sac, ectopic mass appearance, positive fetal cardiac activity), serum human chorionic gonadotrophins (hCG) levels on day 0 , day 4, and day 7, and the duration of hospital stay for women who underwent surgical interventions for treatment of ectopic pregnancy.

\section{Diagnosis and treatment protocol}

Women were diagnosed with ectopic pregnancy when they had positive transvaginal ultrasonography findings (gestational sac, ectopic mass appearance, and positive fetal cardiac activity) and a persistent increase in serial serum hCG levels without the presence of intrauterine pregnancy. Patients were treated using expectant management when spontaneous resorption of ectopic pregnancy was expected in hemodynamically stable patients by a greater than $15 \%$ decrease in their daily serial serum hCG levels. Medical management with methotrexate was given for hemodynamically stable patients who had less than $50 \%$ increase in their serum hCG levels over two consecutive days or patients whose hCG levels had plateaued. Methotrexate intramuscular dose $(50 \mathrm{mg} / \mathrm{m} 2$ body surface area) was administered and serial serum hCG levels were measured on day 0 , day 4 , and day 7. If the hCG levels on the 7 th day were at least
$15 \%$ lower than the levels on the 4th day, then serial measurements of hCG at a weekly basis were performed until the levels plunged to values less than $5 \mathrm{mIU} / \mathrm{L}$. Single-dose methotrexate regimen was considered successful when hCG levels declined to less than $5 \mathrm{mIU} / \mathrm{L}$ without further administration of methotrexate or need for surgery. If the hCG levels were decreased by less than $15 \%$ between day 4 and day 7, a second dose of methotrexate was offered. For the two-dose regimen, two doses of methotrexate $(50 \mathrm{mg} / \mathrm{m} 2$ body surface area) were used on day 0 and day 4 for patients with high hCG levels (example- hCG $>5000 \mathrm{mIU} / \mathrm{mL}$ + ectopic cardiac activity). If the hCG levels were dropped by $\geq 15 \%$ from day 4 to day 7 , then serial measurements of hCG were followed at a weekly basis until the levels plunged into values less than $5 \mathrm{mIU} / \mathrm{L}$. A third methotrexate dose was required if the hCG levels were decreased by less than $15 \%$ between the fourth and seventh day. Moreover, if the hCG levels were not declined by at least $15 \%$ between day 7 and day 11 , surgical intervention was required.

\section{Statistical analysis}

Statistical analysis was performed using Statistical package for social sciences) SPSS 15.0 software (Chicago, Illinois, USA). One-way analysis of variance (ANOVA) was used to test differences between different groups followed by Tukey-Kramer or Bonferroni post-hoc tests for multiple comparisons according to the distribution type of variables in these groups. The categorical variables were presented as the number of cases and the percentage, and the continuous variables were presented as mean \pm standard deviation (SD). Statistical significance was set at $\mathrm{p}<0.05$.

\section{RESULTS}

A total of 77 cases with ectopic pregnancy were diagnosed in Damascus University Hospital of OBGYN. According to the clinical protocol of the management, 16 cases $(20.8 \%)$ of the 77 patients were treated using expectant management (Group 1), 10 patients $(13.0 \%)$ were treated with single-dose methotrexate regimen (Group 2), 5 patients $(6.5 \%)$ were treated with two-dose methotrexate regimen (Group 3), and the remaining 46 (59.7\%) patients underwent surgical intervention (Group 4). The demographic characteristics and the ultrasonography findings of the patients with ectopic pregnancy are presented in Table 1 .

Patients' age ranged between 16 and 40 years, and most cases of ectopic pregnancy patients aged between 20-40 years $(92.3 \%)$ with higher frequency of distribution between $30-40$ years $(48.1 \%)$. Smoking habit was found in about $14.3 \%$ of women diagnosed with ectopic pregnancy while both alcohol and smoking habits were found only in $1.3 \%$ of the patients. No significant difference was observed in the age of patients between the groups. 
The most frequent main complaint among ectopic pregnancy patients was pain with vaginal bleeding in $48.1 \%$ of the patients. Also, $22.1 \%$ of the patients had abdominal pain as the main complaint. However, patients in the four groups did not differ significantly in the symptoms associated with ectopic pregnancy.

The most common encountered risk factors of ectopic pregnancy among patients were the history of previous intra-abdominal or pelvic surgery $(57.1 \%)$ followed by the history of miscarriage $(41.6 \%)$. The history of ectopic pregnancy was found only in $2.6 \%$ of the patients. Smoking was also found in $14.3 \%$ of the patients. No significant differences of the risk factors were observed between groups. Transvaginal ultrasonography revealed that most patients had gestational sac plus ectopic mass appearance $(90.9 \%)$. Other less frequent findings were either only an ectopic mass or a gestational sac. Similarly, all the four groups did not differ significantly in terms of these diagnostic ultrasonography findings.

Table 1: Clinical presentation, history, and ultrasonography findings in patients with ectopic pregnancy.

\begin{tabular}{|c|c|c|c|c|c|c|}
\hline & $\begin{array}{l}\text { Total } \\
(n=77)\end{array}$ & $\begin{array}{l}\text { Group } 1 \\
\text { Expectant } \\
\text { management } \\
(\mathrm{n}=16)\end{array}$ & $\begin{array}{l}\text { Group } 2 \\
\text { Single-dose } \\
\text { methotrexate } \\
(\mathbf{n}=\mathbf{1 0})\end{array}$ & $\begin{array}{l}\text { Group } 3 \\
\text { Two-dose } \\
\text { methotrexate } \\
(\mathrm{n}=5)\end{array}$ & $\begin{array}{l}\text { Group } 4 \\
\text { Surgical } \\
\text { intervention } \\
(n=46)\end{array}$ & $P$ value \\
\hline Age & $28.1 \pm 6.22$ & $25.88 \pm 7.47$ & $28.60 \pm 6.47$ & $25.60 \pm 4.39$ & $29.02 \pm 5.76$ & 0.272 \\
\hline Clinical presentation $(\%)$ & & & & & & 0.189 \\
\hline Pain & $37(48.1)$ & $6(37.5)$ & $1(10)$ & $0(0)$ & $10(21.7)$ & \\
\hline Vaginal bleeding & $17(22.1)$ & $0(0)$ & $1(10)$ & $1(20)$ & $3(6.5)$ & \\
\hline Pain + vaginal bleeding & $9(11.7)$ & $8(50)$ & $4(40)$ & $1(20)$ & $24(52.2)$ & \\
\hline Pain + amenorrhea & $6(7.8)$ & $0(0)$ & $0(0)$ & $2(40)$ & $4(8.7)$ & \\
\hline Vaginal bleeding + amenorrhea & $5(6.5)$ & $1(6.3)$ & $1(10)$ & $0(0)$ & $1(2.2)$ & \\
\hline $\begin{array}{l}\text { Pain }+ \text { vaginal bleeding }+ \\
\text { amenorrhea }\end{array}$ & $3(3.9)$ & $1(6.3)$ & $3(30)$ & $1(20)$ & $4(8.7)$ & \\
\hline \multicolumn{7}{|l|}{ History $(\%)$} \\
\hline $\begin{array}{l}\text { Previous intra-abdominal } \\
\text { surgery }\end{array}$ & $44(57.1)$ & $8(50)$ & $8(80)$ & $3(60)$ & $25(54.3)$ & 0.466 \\
\hline History of infertility treatment & $0(0)$ & $0(0)$ & $0(0)$ & $0(0)$ & $0(0)$ & 0 \\
\hline History of ectopic pregnancy & $2(2.6)$ & $0(0)$ & $0(0)$ & $0(0)$ & $2(4.3)$ & 0.721 \\
\hline History of miscarriage & $32(41.6)$ & $7(43.8)$ & $5(50)$ & $3(60)$ & $18(39.1)$ & 0.712 \\
\hline Smoking & $11(14.3)$ & $1(6.3)$ & $3(30)$ & $2(40)$ & $5(10.9)$ & 0.900 \\
\hline Gestational age & $53.9 \pm 27.9$ & $49 \pm 13.53$ & $57 \pm 18.61$ & $42 \pm 11.07$ & $56.2 \pm 33.83$ & 0.609 \\
\hline Findings on USG (\%) & & & & & & 0.233 \\
\hline Gestational sac & $1(1.3)$ & $1(6.3)$ & $0(0)$ & $0(0)$ & $0(0)$ & \\
\hline Ectopic mass appearance & $3(3.9)$ & $1(6.3)$ & $1(10)$ & $1(20)$ & $0(0)$ & \\
\hline $\begin{array}{l}\text { Gestational sac + ectopic mass } \\
\text { appearance }\end{array}$ & $70(90.9)$ & $14(87.5)$ & $9(90)$ & $3(60)$ & $44(95.7)$ & \\
\hline $\begin{array}{l}\text { Gestational sac }+ \text { ectopic mass } \\
\text { appearance }+ \text { positive fetal } \\
\text { cardiac activity }\end{array}$ & $3(3.9)$ & $0(0)$ & $0(0)$ & $1(20)$ & $2(4.3)$ & \\
\hline
\end{tabular}

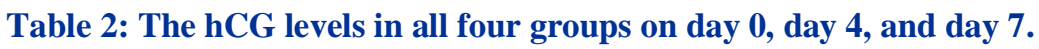

\begin{tabular}{|c|c|c|c|c|c|}
\hline & $\begin{array}{l}\text { Group } 1 \\
\text { Expectant } \\
\text { management }(n=16)\end{array}$ & $\begin{array}{l}\text { Group } 2 \\
\text { Single-dose } \\
\text { methotrexate } \\
(\mathbf{n}=\mathbf{1 0})\end{array}$ & $\begin{array}{l}\text { Group } 3 \\
\text { Two-dose } \\
\text { methotrexate } \\
(\mathbf{n}=5)\end{array}$ & $\begin{array}{l}\text { Group } 4 \\
\text { Surgical } \\
\text { intervention } \\
(n=46)\end{array}$ & P value \\
\hline Day 0 & $1276 \pm 912.2^{1,2,3}$ & $2461 \pm 995.5^{4}$ & $2652 \pm 831.5^{2,5}$ & $8432 \pm 6611^{3,4}$ & $<0.001^{*}$ \\
\hline Day 4 & $1152 \pm 672.0^{1,2}$ & $2241 \pm 877.4$ & $2128 . \pm 617.1$ & - & $0.002^{*}$ \\
\hline Day 7 & $963 \pm 550.7$ & $1654 \pm 870.8$ & $1752 \pm 705.2$ & - & 0.024 \\
\hline
\end{tabular}

* statistically significant between groups; ${ }^{1}$ : group 1 versus group $2,{ }^{2}$ : group 1 versus group $3,{ }^{3}$ : group 1 versus group $4,{ }^{4}:{ }^{4}$ : group 2 versus group $4,{ }^{5}$ : group 3 versus group 4 . 
Table 3: Changes in the hCG levels from day 0 to day 4 and from day 4 to day 7 after methotrexate administration.

\begin{tabular}{|c|c|c|c|c|}
\hline & $\begin{array}{l}\text { Group } 1 \\
\text { Expectant management } \\
(n=16)\end{array}$ & $\begin{array}{l}\text { Group } 2 \\
\text { Single-dose methotrexate } \\
(\mathrm{n}=10)\end{array}$ & $\begin{array}{l}\text { Group } 3 \\
\text { Two-dose methotrexate } \\
(\mathbf{n}=5)\end{array}$ & $P$ value \\
\hline Day 4-0 & $124 \pm 112.5(9.72 \%)$ & $220 \pm 129.5(8.94 \%)$ & $524 \pm 254.7(19.77 \%)$ & 0.247 \\
\hline Day 7-0 & $189 \pm 177.1(16.41 \%)$ & $587 \pm 260.7^{1}(26.19 \%)$ & $376 \pm 154.6(17.67 \%)$ & $0.023^{*}$ \\
\hline
\end{tabular}

* statistically significant ${ }^{1}$ : group 1 versus group 2.

Table 4: Differences between the hCG levels from day 0 to day 4 in ectopic pregnancy patients.

\begin{tabular}{|lllll|} 
& $\begin{array}{l}\text { Group 1 } \\
\text { Expectant management } \\
(\%)\end{array}$ & $\begin{array}{l}\text { Group 2 } \\
\text { Single-dose methotrexate } \\
(\%)\end{array}$ & $\begin{array}{l}\text { Group 3 } \\
\text { Two-dose methotrexate } \\
(\%)\end{array}$ & $\begin{array}{l}\text { Total } \\
(\%)\end{array}$ \\
\hline Negative value & $12(75)$ & $8(80)$ & $5(100)$ & $25(80.6)$ \\
\hline Positive value & $4(25)$ & $2(20)$ & $0(0)$ & $6(19.4)$ \\
\hline Total & $16(100)$ & $10(100)$ & $5(100)$ & $31(100)$ \\
\hline
\end{tabular}

Table 5: Differences between the hCG levels from day 4 to day 7 in ectopic pregnancy patients.

\begin{tabular}{|c|c|c|c|c|}
\hline & $\begin{array}{l}\text { Group } 1 \\
\text { Expectant management } \\
(\mathrm{n}=16)(\%)\end{array}$ & $\begin{array}{l}\text { Group } 2 \\
\text { Single-dose methotrexate } \\
(\mathbf{n}=10)(\%)\end{array}$ & $\begin{array}{l}\text { Group } 3 \\
\text { Two-dose methotrexate } \\
(n=5)(\%)\end{array}$ & $\begin{array}{l}\text { Total } \\
(\mathbf{n}=77) \\
(\%)\end{array}$ \\
\hline Negative value & $14(87.5)$ & $9(90)$ & $5(100)$ & $28(90.3)$ \\
\hline Positive value & $2(12.5)$ & $1(10)$ & $0(0)$ & $3(9.7)$ \\
\hline Total & $16(100)$ & $10(100)$ & $5(100)$ & $31(100)$ \\
\hline
\end{tabular}

The measured hCG concentrations in the four groups on Day 0, Day 4, and Day 7 is shown in Table 2.

Table 6: The need for surgical intervention.

\begin{tabular}{|ll|}
\hline Modality & N $(\%)$ \\
\hline Surgery & $46(59.7)$ \\
\hline Expectant management + surgery & $9(11.7)$ \\
\hline Expectant management & $7(9.1)$ \\
\hline Single-dose methotrexate & $7(9.1)$ \\
\hline Two-dose methotrexate & $3(3.9)$ \\
\hline Single-dose methotrexate + surgery & $3(3.9)$ \\
\hline Two-dose methotrexate + surgery & $2(2.6)$ \\
\hline
\end{tabular}

Serum hCG levels decreased between day 0 and day 4 in $75 \%$ of the patients who were offered the expectant management (group 1), in $80 \%$ of the patients who received a single methotrexate dose (group 2), and in $100 \%$ of the patients who received two or more doses of methotrexate (group 3). Moreover, the hCG concentrations decreased on day 7 in comparison to day 4 in $87.5 \%, 90 \%$, and $100 \%$ in groups 1, 2 and 3 respectively. The complete plunge in hCG levels was observed in $80.6 \%$ between day 4 and day 0 , and $90.3 \%$ between day 7 and day 4 in all patients with ectopic pregnancy (Tables 4 and 5).

The need for surgical intervention among patients with ectopic pregnancy is summarized in Table 6. More than half $(56.2 \%)$ of the patients treated with expectant management needed a surgical intervention. About $30 \%$ of the women who had received the single-dose methotrexate regimen also needed a surgical intervention. Moreover, $40 \%$ of the patients treated with two-dose methotrexate regimen needed a surgical intervention.

Table 7: Types of surgical intervention.

\begin{tabular}{|ll|}
\hline Modality & N $(\%)$ \\
\hline Salpingectomy total & $59(76.6)$ \\
\hline No surgery performed & $16(20.8)$ \\
\hline Salpingostomy partial & $1(1.3)$ \\
\hline Transampullary expression or milk-out & $1(1.3)$ \\
\hline
\end{tabular}

In terms of surgical procedure types, total salpingectomy was performed for $76.6 \%$ of the patients with ectopic pregnancy who needed a surgical intervention.

The lowest percentage $(1.3 \%)$ of patients received either partial salpingostomy or trans-ampullary expression (milking). On the other hand, only $20.8 \%$ of the patients did not need surgical intervention. Types of surgical interventions are summarized in Table 7.

\section{DISCUSSION}

The present study investigated the outcomes of ectopic pregnancy in patients who attended the Damascus University Hospital of OBGYN, Syria. Management of ectopic pregnancy depends on the hemodynamic stability 
of the patient, the hCG levels, as well as the size of the ectopic pregnancy and the presence of fetal cardiac activity, in addition to the fertility needs and compliance with long-term follow-up. ${ }^{1}$

The average level of the hCG in patients treated with expectant management was $1276 \mathrm{mIU} / \mathrm{L}$ in the present study. Expectant management is more preferred over medical management with methotrexate when the initial serum hCG concentrations are less than $1500 \mathrm{mIU} / \mathrm{L}$ in the unruptured tubal ectopic pregnancy. ${ }^{8,9}$ More than half $(56.2 \%)$ of the patients in the present study treated with expectant management needed further surgical intervention, and spontaneous resolution occurred only in $43.8 \%$ of these patients. These high rates could be attributed to the fact that patients with ectopic pregnancy are usually referred to our tertiary hospital for medical treatment or surgical intervention.

Medical management with methotrexate is regarded an effective treatment modality for ectopic pregnancy patients with appropriate criteria for medical management including hemodynamic stability and fertility demand. In the present study, the single-dose methotrexate regimen was associated with $8.94 \%$ decrease in hCG levels between day 4 and day 0 while the two-dose methotrexate regimen was associated with $19.77 \%$ decrease in hCG levels. Between day 4 and day 7 , the decrease in hCG levels was also further $26.19 \%$ in single-dose methotrexate regimen and $17.67 \%$ in two-dose methotrexate regimen. The changes in hCG levels between day 4 and day 7 were used to measure the success of methotrexate therapy and the changes in hCG levels between day 4 and day 0 were used to predict the success of methotrexate therapy. These changes ranged in the literature from $9.08 \%$ to $22.0 \%$ between day 0 and day $4 .{ }^{10-13}$ Other studies reported that treatment success might not be predicted by the decrease in hCG levels. ${ }^{7}$

In this study, $70 \%$ of the women who had received the single-dose methotrexate regimen and $40 \%$ of the patients treated with two-dose methotrexate regimen needed no further surgical interventions. The success rate of the single-dose methotrexate regimen was reported in the literature to be between $52 \%$ and $94 \%$ which goes in line with the results of the present study. ${ }^{14,15}$ The lower success rate of the two-dose methotrexate regimen (40\%) found in the present study could be explained by the high hCG levels in patients treated with two-dose methotrexate regimen (average $=2652 \mathrm{mIU} / \mathrm{L}$ ). In the literature, serum levels of hCG have been correlated with the success rate of methotrexate medical therapy which supports the explanation for our findings. ${ }^{7,11,14,16}$ In addition, the American Society for Reproductive Medicine Guidelines suggest that medical treatment with single-dose methotrexate regimen fails at high initial serum hCG levels.

Moreover, no significant difference was observed in the present study between the success rates of the single-dose and two-dose methotrexate regimens (40\% and 30\%, respectively). These results are in accordance with similar findings reported in previous studies including a prospective randomized trial. ${ }^{17-19}$ These observations suggest that the single-dose methotrexate regimen should be considered when the side effects preclude the use of multiple-dose methotrexate regimens.

\section{Limitations}

Our limitations included a relatively small sample size collected through simple sampling in our university hospital with the data collection also done retrospectively. Our hospital is known to be a center for referral of clinically severe cases in Obstetrics and Gynecology and such is the case in our data being more skewed towards requiring surgical intervention. Prospective randomized studies involving a larger number of patients are needed to substantiate our findings.

\section{CONCLUSION}

The results of the present study showed that success rate of the expectant management was $56.25 \%$, for the singledose methotrexate regimen was $70 \%$, and in the two-dose methotrexate regimen was $40 \%$ of the patients with ectopic pregnancy. These rates were correlated with the initial concentrations of serum hCG concentrations. The changes in hCG levels between day 0 and day 4 after receiving methotrexate may predict the outcomes of therapy.

Funding: No funding sources

Conflict of interest: None declared

Ethical approval: The study was approved by the Institutional Ethics Committee

\section{REFERENCES}

1. Jurkovic D, Memtsa M, Sawyer E, Donaldson ANA, A Jamil A, Schramm K et al. Single-dose systemic methotrexate vs expectant management for treatment of tubal ectopic pregnancy: a placebo-controlled randomized trial. Ultrasound Obstet Gynecol. 2017;49:171-6.

2. American College of Obstetricians and Gynecologists. ACOG practice bulletin: tubal ectopic pregnancy. Obstet Gynecol. 2018;131(3):e91-103.

3. Farquhar CM. Ectopic pregnancy. Lancet. 2005;366:583-91.

4. Kathpalia BSK, Arora CD, Sandhu N, Sinha P. Ectopic pregnancy: Review of 80 cases. MJAFI. 2018;74:172-6.

5. Lipscomb GH, Givens VM, Meyer NL, Bran D. Comparison of multidose and single-dose methotrexate protocols for the treatment of ectopic pregnancy. Am J Obstet Gynecol. 2005;192:1844-7.

6. Inal ZO, Inal HA. Comparison of Four Methods of Treating Ectopic Pregnancy: A Retrospective Cohort Study. Geburtsh Frauenheilk. 2018;78:70-7. 
7. Dogan A, Gulhan I, Uyar I, Ekin A, Gezer C, Bilgin $\mathrm{M}$ et al. Methotrexate treatment in progressive tubal ectopic pregnancies and hCG-related clinicosurgical implications. Kaohsiung J Med Sci. 2016;32:317-22.

8. Levin I, Tsafrir Z, Sa'ar N, Lessing J, Avni A, Gamzu $\mathrm{R}$ et al. Watchful waiting" in ectopic pregnancies: a balance between reduced success rates and less methotrexate. Fertil Steril. 2011;95:1159-60.

9. Kirk E, Van Calster B, Condous G, Papageorghiou AT, Gevaert O, Huffel SV et al. Ectopic pregnancy: using the hCG ratio to select women for expectant or medical management. Acta Obstet Gynecol Scand. 2011;90:264-72.

10. Ustunyurt E, Duran M, Coskun E, Ustunyurt OB, Simsek H. Role of initial and day 4 human chorionic gonadotropin levels in predicting the outcome of single-dose methotrexate treatment in women with tubal ectopic pregnancy. Arch Gynecol Obstet. 2013;288:1149-52.

11. YildırımA, Cirık DA, Altay M, Gelisen O. Early prediction for the requirement of second or third dose methotrexate in women with ectopic pregnancy, treated with single-dose regimen. Arch Gynecol Obstet. 2015;291:1327-32.

12. Agostini A, Blanc K, Ronda I, Romain F, Capelle M, Blanc B. Prognostic value of human chorionic gonadotropin changes after methotrexate injection for ectopic pregnancy. Fertil Steril. 2007;88:504-506.

13. Bottin P, Gnisci A, Crochet, Butzbach P, Cravello L, Gamerre $\mathrm{M}$ et al. Prognostic value of early hCG changes after methotrexate injection for ectopic pregnancy. Gynecol Obstet Fertil. 2014;42:3-7.

14. Sagiv R, Debby A, Feit H Bina Cohen-Sacher B, Ran Keidar R, Golan A. The optimal cutoff serum level of human chorionic gonadotropin for efficacy of methotrexate treatment in women with extrauterine pregnancy. Int J Gynaecol Obstet. 2012;116:101-4.

15. Gamzu R, Almog B, Levin Y, Jaffa A, Lessing JB, Baram A. Efficacy of methotrexate treatment in extrauterine pregnancies defined by stable or increasing human chorionic gonadotropin concentrations. Fertil Steril. 2002;77:761-5.

16. Nowak-Markwitz E, Michalak M, Olejnik M, Spaczynski M. Cutoff value of human chorionic gonadotropin in relation to the number of methotrexate cycles in the successful treatment of ectopic pregnancy. Fertil Steril. 2009;92:1203-7.

17. Guvendag Guven ES, Dilbaz S, Dilbaz B, Yildirim BA, Akdag D, Haberal A. Comparison of single and multiple dose methotrexate therapy for unruptured tubal ectopic pregnancy: a prospective randomized study. Acta Obstet Gynecol Scand. 2010;89:889-95.

18. Natale A, Busacca M, Candiani M, Gruft L, Izzo S, Felicetta I et al. Human chorionic gonadotropin patterns after a single dose of methotrexate for ectopic pregnancy. Eurn J Obstet Gynecol Reprod Biol. 2002;100:227-30.

19. Potter MB, Lepine LA, Jamieson DJ. Predictors of success with methotrexate ntreatment of tubal ectopic pregnancy at Grady Memorial Hospital. Am J Obstet Gynecol. 2003;188:1192-4.

Cite this article as: Alawdi $\mathrm{SH}$, Roumieh M, Alhalabi M. Management outcomes of ectopic pregnancy depending on different treatment modalities: a cohort study. Int J Reprod Contracept Obstet Gynecol 2021;10:842-7. 